\title{
Group Participation and Interaction in ESL Wiki Collaborative Writing among Malaysian Gifted Students
}

\author{
Lisa S. L. Kwan ${ }^{1} \&$ Melor Md Yunus ${ }^{1}$ \\ ${ }^{1}$ Faculty of Education, Universiti Kebangsaan Malaysia (UKM), Bangi, Selangor, Malaysia \\ Correspondence: Lisa S. L. Kwan, Faculty of Education, Universiti Kebangsaan Malaysia (UKM), 43600 Bangi, \\ Selangor, Malaysia. Tel: 60-16-912-1965. E-mail: lisakwan24@gmail.com
}

Received: June 24, 2014 Accepted: October 29, 2014 Online Published: December 20, 2014

doi:10.5539/ass.v11n2p59 URL: http://dx.doi.org/10.5539/ass.v11n2p59

\begin{abstract}
In the Malaysian Education Ministry's Education Transformation 2013-2025, there is an emphasis on English language proficiency, collaborative practices and ICT, and concern for the educational needs of gifted students. The study aimed to align with the Ministry's initiatives by exploring the use of wikis in ESL collaborative writing among gifted students, particularly group participation and interaction. The mixed-method case study employed questionnaires, online interviews and observations to collect data from 74 Form 4 gifted students from PERMATApintar National Gifted Centre, UKM. The study found that group participation and collaboration was not ideal, but students gained from interactions with others on the wiki. These findings were discussed in detail with regards to the literature and arising issues. Hence, wikis proved to be an interesting alternative for ESL collaborative writing that is capable of motivating and fostering collaborative language learning efforts among gifted students.
\end{abstract}

Keywords: gifted students, wikis, English language learning, collaborative writing, ESL

\section{Introduction}

In the Malaysian context, English is a second language (ESL). However, despite English being a compulsory subject in all schools across the country, English language proficiency is markedly weak. Only 23\% Bumiputera, $42 \%$ Chinese and 35\% Indian students achieved at least a Credit benchmarked to Cambridge 1119 in 2010 (Ministry of Education, 2012). Thus, in line with the To Uphold Bahasa Malaysia and Strengthen the English Language (MBMMBI) policy, the Ministry is making efforts to strengthen the language by increasing English exposure, among others. Therefore, there is a strong emphasis on enhancing English language proficiency, which the researcher believes can be done through learning collaboratively.

Collaborative practices are increasingly encouraged with the advent of Web 2.0 technologies (Kessler, Bikowski, \& Boggs, 2012). Godwin-Jones (2008) believed that Web 2.0 tools, like social networks, blogs and wikis, that enhance communication and human interaction have a great potential to be harnessed for language learning. This can be seen by the positive effects on students' language learning through the use of web tools such as Facebook and blogs (Omar, Embi, \& Yunus, 2012; Said et al., 2013). Furthermore, these Web 2.0 tools also created a shift in the roles of students and instructors. Students are no longer passive recipients of information, but active participants in the learning process while constantly learning collaboratively with others (Anderson, 2010). This is supported by O'Sullivan and Samarawickrema who asserted that technology pushes the social aspect of learning to new levels by "unprecedented sharing and collaboration between users, (and) the formation of new learner identities or subjectivities and communities of learning" (2008, p. 713). Lowry, Curtis and Lowry (2004) stated that Internet tools provided unique affordances for collaboration that meets the demands of globalisation.

Gifted children, on the other hand, are a specific group of the country's school-going population that has special educational needs. They exhibit particular characteristics, learn in ways far different from their peers and possess potential to excel in certain domains, given the right tools and learning environment (Aliza \& Hamidah, 2009; Davis \& Rimm, 2005; Munro, 2005; Ruf, 2003). This is important, as gifted students were found to also experience language learning difficulties such as speaking in English, grammar and lack of vocabulary (Yunus, Sulaiman, Kamarulzaman, \& Ishak, 2013). Incorporating technology for language learning with Malaysian gifted students holds much promise as they are exposed to and familiar with Web 2.0, and recognise its benefits for language learning purposes (Yunus \& Kwan, 2013; Yunus, Kwan, \& Noriah, 2012). Thus, this paper aims to 
explore the use of wikis in ESL collaborative writing among gifted students, particularly in terms of group participation and interaction.

\section{Literature Review}

\subsection{Collaborative Learning}

Collaboration is a process of mutual engagement and interaction to create shared knowledge which may not be achieved otherwise, and is the collective effort of the members that may result in something more than the sum of its parts (Chu \& Kennedy, 2011; Ta-Elhasid \& Meishar-Tal, 2007). With collaboration, students can "potentially produce better results than individually" (Pinheiro, 2012, p. 10). There are certain concepts in collaboration that often appear together, yet need to be distinguished: 'cooperation' and 'collaboration'. Cooperation is when the work required for a task is divided among the participants who then work independently and separately (Ta-Elhasid \& Meishar-Tal, 2007); while collaboration involves participants who are mutually engaged and coordinate their efforts to accomplish a task together (Ta-Elhasid \& Meishar-Tal, 2007; Resta \& Laferrière, 2007). The principles behind collaborative learning are founded upon two theories: personal constructivism or constructivism, and social constructivism.

Constructivists, such as Piaget, believed that students construct meanings as they interact with the physical, social and mental worlds they inhabit, and they make sense of their experiences by building and adjusting internal knowledge structures that collect and organise their perceptions and reflections of reality (Swan, 2005). According to Brown (2007), in terms of language acquisition, constructivism emphasises both the learner's role in constructing meaning out of available linguistic input and the importance of social interaction in creating a new linguistic system. In the classroom, constructivism encourages learning through interaction with others such as teachers and peers. Such interactions enhance an individual's zone of proximal development (ZPD), a metaphorical zone where students advance and achieve more than they are capable of, and allow for meaningful construction of knowledge.

Vygotsky emphasised the importance of social interactions either between peers or between weaker and better students that support learning by extending one's knowledge from a lower level to a higher level of understanding. This means that meaning is socially constructed through communication, activity and interaction with others and the environment (Swan, 2005). Vygotsky argued that learning is not merely an assimilation or installation of new knowledge by individual students; rather "it is the process by which learners are integrated into a knowledge community" (Woo \& Reeves, 2007, p. 18). The way students learn is shaped by their relationships with others (Vygotsky, 1978) and through collaboration and sharing information in authentic contexts (Hadjerrouit, 2012). Thus, according to social constructivism, language develops primarily from social interaction in an environment where students are able to achieve a higher level of competency and performance (Lightbown \& Spada, 2006).

Collaborative learning can then be defined as students, or students with teachers, working together while combining intellectual efforts to achieve shared learning goals (Barkley, Cross, \& Major, 2005; Chu \& Kennedy, 2011). It involves active engagement in the learning process whereby knowledge is not passively transferred but mutually constructed in a natural authentic social context (Woo, Chu, Ho, \& $\mathrm{Li}, 2011$ ). As students collaborate, they facilitate each other's learning and can achieve more as a group than as individuals, consequently forming a collectively more meaningful learning environment (Thompson \& Ku, 2006; Witney \& Smallbone, 2011). One form of collaborative learning is collaborative writing. Conventionally, these activities were done in a face-to-face mode, but there has been a rise in popularity in the use of technology and online tools for collaborative writing, one of which is wikis (Chong, Tan, \& Abdullah, 2011; Witney \& Smallbone, 2011; Wang, 2012).

\subsection{Wikis and Collaborative Writing}

A wiki is basically a webpage whose content can be modified or edited by its users, making it a collaborative platform on texts and hypertexts (Ebersbach, Glaser, Heigl, \& Warta 2008). Chawner and Lewis state that wikis "free writers from the burden of mastering HTML editing and file transfer software" (2006, p. 33). Without having to know website programming, users can edit or modify content directly on the page (Charles \& Ranmi, 2007; Wang, 2012). An example of a successful wiki is Wikipedia, the open online encyclopedia (Wang, 2012).

The wiki's features and affordances are able to provide support for collaborative work; in fact was deemed created specifically for collaboration (Augar, Raitman, \& Zhou, 2004). Others agree that wikis possess huge potential for fostering collaborative work because it is easily edited and the group's writing progress and participation can be monitored (Carr, Morrison, Cox, \& Deacon, 2007; Ma \& Wang, 2012). Moreover, wikis 
offers an environment for students to engage with others in an online community that shares knowledge and goals (Coniam \& Lee, 2008; Chong et al., 2011).

Likewise, collaborative writing efforts are enhanced through the use of wikis. O'Reilly (2005) acknowledges this tool as an instrument for collective intelligence in the teaching of writing, where knowledge and information can be constructed together. Besides that, wikis provided a platform for authentic writing among upper secondary students in Malaysia (Chong et al., 2011). Students' writing skills were also improved (Mak \& Coniam, 2008) while also honing communicative skills by conveying their work to an authentic audience (Butler-Pascoe, 2011).

However, students seemed to be too accustomed to traditional writing methods and were unable to adjust to collaborative writing on the wikis (Lin \& Yang, 2011b). A wiki learning environment requires active engagement and participation in the learning process for meaningful learning, as compared to previous methods of teacher-centred approaches that were more passive and inflexible. Without a change in the culture or mentality of both students and teachers, learning goals may not be achieved (Collis \& Moonen, 2008).

Ultimately, while wikis may prove beneficial for collaborative learning, they do not automatically ensure collaboration. The students and teachers themselves need to be mentally and pedagogically prepared in order to truly foster collaborative learning (Cole, 2009; Hadjerrouit, 2012). Wikis have been found to enhance collaborative writing in terms of group participation and interaction which are now explored from the literature.

\subsection{Group Participation on Wikis}

In collaborative writing, group participation is imperative for its success and achievement of shared goals. Wikis' 'openness' allowed members to edit the work at any time and place encouraged equal participation among group members (Elgort, Smith, \& Toland, 2008; Zailin, Nik Aloesnita, \& Ainol, 2012). It was found that groups of university students would typically designate a leader and roles for members that enabled students to contribute equally to the task (Zailin et al., 2012). Overall, wikis helped students work better as a group and led to general satisfaction over group participation and effort (Woo et al., 2011; Zailin et al., 2012).

However, working together also caused a lot of friction within the group. Mixed-ability groups tend to incite more conflicts. Olivo's study with university students reported students who could not work with their group members due to "substantial differences in diligence, expectations, and working styles" (2012, p. A87). In extreme cases, some students worked alone to compensate for the others' slack. Ultimately, the best students were the ones who seemed to be the most frustrated and bear the heaviest burden of the group work (Olivo, 2012). Thus, using wikis did not necessarily guarantee equal participation.

It was found that, instead of mutual engagement throughout the writing process, students divided the responsibilities and worked individually, resulting in fragmented work (Hadjerrouit, 2012; Wang, 2012). Hadjerrouit (2012) reported that the students worked on individual sections of the wikis, and seldom revised each other's work substantially. Likewise, some students still preferred working individually (Elgort et al., 2008; Zailin et al., 2012). This implies that even though research supports the pedagogical value of collaborative work, many students possess neither the desire nor teamwork skills needed to work collaboratively (Harper, 2012).

Despite wikis' potential to motivate and cultivate student interest through active learning, students were rather inactive on the wikis. Chong et al. (2011) found that the students did not really actively participate in the project assigned. Besides that, a common phenomenon was the "last minute" habit, where students left off working on the assignment to the last possible moment (Cole, 2009; Wang, 2012). Furthermore, students showed no initiative to do more than was necessary, resorting to doing the bare minimum (Wang, 2012), while only a few hardworking students did, although inconsistently (Olivo, 2012). Consequently, in order not to receive a poor grade, the better or more active students would compensate for their less-active members (Olivo, 2012; Wang, 2012). This indicates that wikis may not necessarily ensure students' active participation, and possibly only the better students benefit from their active participation. The following section looks at how wikis have fared in enhancing students' interaction in collaborative writing.

\subsection{Interaction on Wikis}

Wikis have the potential to promote meaningful student interaction (Lin \& Yang, 2011a). Among primary school students in Hong Kong, wikis were found to encourage peer-to-peer interaction and facilitated group work (Woo et al., 2011), while higher education students from both China and the UK were able to collaborate across geographical distances, and found their interaction on the wiki "interesting" and "educationally constructive" (Zou, Xiang, \& Jeaco, 2012, p. 107). Wiki collaborative interactions facilitated mutual construction of knowledge (Hazari, North, \& Moreland, 2009) that stimulated 'cognitive conflicts' as they shared and manipulated collated information that aided in the development of new knowledge (Kimmerle, Cress, \& Held, 
2010). Moreover, wikis provided authentic interaction between university students across countries (Zou et al., 2012).

Besides that, the publicly visible interactions on the wikis were found to be beneficial as well. Students perceived the interaction on wikis as 'transparent' as each student was able to monitor each other's contribution (Zailin et al., 2012). From observing peers' work, students learned vocabulary, spelling, phrases and sentence structure (Lin \& Yang, 2011a) and had improved understanding of the topic (Chong et al., 2011; Olivo, 2012). Not only that, these interactions also made students more conscious and aware of their readers and formal aspects of writing as well as language accuracy (Chong et al., 2011; Ma \& Wang, 2012).

Despite this, ideal meaningful interactions were not always the result. Students preferred working individually and had an individualistic mentality in a collaborative group project. Wang (2012) found that the university students wanted individual grades, even writing in separate paragraphs for instructors to identify individual contributions. Zhang, Peng and Hung (2009) also discovered similar results, where Taiwanese undergraduate students also preferred dividing out the workload and being responsible for respective parts instead of joint construction of knowledge and writing. This shows that students were still very much individualistic-thinking in the wiki group projects.

The interaction and communication on wikis were also considered insufficient. University students reported a preference for face-to-face interaction as the more effective alternative due to the unfamiliarity and asynchronous communication of wikis (Hadjerrouit, 2012; Zailin et al., 2012). Zailin et al. (2012) reported that the university students spent more than half their time on the project in face-to-face mode, also citing a preference for it over online interactions. On the other hand, some students did enjoy the immediate online response they received from their instructor on the wiki (Lin \& Yang, 2011a). Therefore, there are differences in students' preferences when it comes to online versus face-to-face interactions.

\section{Method}

\subsection{Research Design}

The study is an explanatory case study as it allows freedom to explore unknown variables for a comprehensive understanding of the phenomenon under study, that answers the 'how' and 'why' as well as draw links between the wiki project implementation and its effects (Yin, 2009). The study employed mixed methods, quantitative and qualitative, that analyses, merges and compares data from both sources, including survey questionnaires, online interviews and the researcher's observational notes.

\subsection{Respondents}

74 Form 4 students from the PERMATApintar National Gifted Centre of Universiti Kebangsaan Malaysia (UKM), Bangi were involved in the study, consisting of 39 (52.7\%) males and 35 (47.3\%) females, between 15 to 16 years of age. Only 5 Form 4 classes out of the total 7 were given consent to be involved in the study by their teachers, and thus, only these gifted students were included.

\subsection{Procedure}

The students were divided into groups of 4 or 5 with mixed-abilities based on English language achievement, forming a total of 19 groups. A wiki workshop was conducted to help students familiarise with wikis and understand the Collaborative Writing Project (CWP) clearly. The CWP lasted about 5 weeks where students worked in their assigned groups to write a persuasive essay collaboratively. At the end of the CWP, survey questionnaires were administered to all 74 students, and 10 who had given prior consent were interviewed online.

\subsection{Data Analysis}

Returned questionnaires were analysed both quantitatively and qualitatively, using descriptive statistics and thematic coding respectively. Online interviews were transcribed and also similarly analysed using thematic coding. All respondents were coded R01, R02 and so on, while interviewees chose pseudonyms to retain anonymity (Rudolph, Baktio, Law, Datenshi, Mochirimin, Syahira, Jud, Gemma, Dino and AmFi). The researchers' observations on the wikis were also incorporated into the discussion to corroborate or contradict findings from the questionnaires and online interviews.

\section{Findings and Discussion}

This section presents the data collected from the study on how wikis are used in ESL collaborative writing among gifted students in terms of group participation and interaction, and relevant discussion on issues that arise. 


\subsection{Group Participation on the Wiki Collaborative Writing Project (CWP)}

This subsection portrays the students' responses regarding the group dynamics in the CWP wiki groups, including the appointment of a leader/s, designation of roles and workload as well as group cooperation. Most students (33.8\%) generally did not agree nor disagree with the statement that their group had a leader(s). $33.8 \%$ of gifted students also disagreed and thus, did not have a leader, while $32.4 \%$ did. This indicates that gifted students worked differently when put in groups-some had leaders, while others did not. Similarly, most students $(43.2 \%)$ neither agreed nor disagreed that they had clearly defined roles for their group members $(\mathrm{M}=3.00)$. $29.7 \%$ of gifted students stated that their groups did not designate roles, while $27.1 \%$ had clear roles for their group members. On the other hand, $36.5 \%$ of students said their groups divided the workload amongst themselves, but $23.0 \%$ said theirs did not $(\mathrm{M}=3.19)$. This indicates that most groups did not make explicit appointments of leaders, but had leaders who naturally took up the role and delegated the tasks (Baktio, Jud). While almost half of the students $(48.7 \%)$ agreed that all their group members did their fair share of the work for the project, $23.0 \%$ did not think so $(\mathrm{M}=3.42)$. However, Rudolph admitted that, even though each member's contribution to the project may not have been "equal" per se, it was sufficient; although not all were satisfied with that (Baktio, Law).

In other times, there were two types of uneven participation in the groups: delayed, and tapered off. The former referred to when some members did not contribute in the early phases of the project, but only got involved in later phases; the latter refers to the opposite. They could be due to procrastination and bad last-minute habits, and a lack of commitment or other priorities, respectively. In addition, there was a "compensation strategy" in most wiki groups, where gifted students "cover" for each other at different phases. If one member did not contribute as much in one phase, they would make an effort to contribute more in another; and in the meantime, the other members would compensate for the slack. In the study, the gifted students also reported that they were often left to manage the workload alone at certain phases in the project. Often, it was the better students who had to shoulder the heaviest responsibility.

On the other extreme, one group apparently had neither a leader nor discussions to delegate tasks. Syahira described it as such: "its like we just do whatever we want without proper discussion". This, unfortunately, she believes may have affected the quality of the group's final writing. Rudolph explained that his group had phase leaders instead of one single leader for the entire CWP. This depicts a very divisive form of cooperation, where workload is divided and separate from each other. Hence, despite gifted students 'collaborating' on the wiki project, some were really merely 'cooperating'.

On the other hand, there were gifted students who remained true to genuine collaboration, where all members were involved in all phases of the writing. Writing was divided into feasible chunks only after discussing and brainstorming together. As a result, good essays were produced and the process was meaningful. However, some students preferred working alone rather than in a group. Nevertheless, in general, this study did not find that gifted students had an overwhelming desire to work alone instead of collaboratively.

Another finding was that students tend to be individualistic, despite working collaboratively in a group. Gifted students were concerned with evaluation and marks, and specified with a byline who contributed what section of the page. This implies a strong individualistic 'this is mine, that is yours' mentality. The exam-oriented Malaysian education system may have instilled an individualistic mentality in students, where they would not contribute if there were no marks to be gained from it. Ironically, despite that, majority of gifted students felt they worked well together on the wikis.

\subsection{Interaction on the Wiki Collaborative Writing Project (CWP)}

Interaction on the wiki CWP helped improve many aspects of gifted students' English language learning, including language aspects, topical knowledge and writing. From the study, gifted students were able to improve vocabulary, syntax and grammar, especially from observing better students' writing and exchanging feedback for error correction. The data showed that, in general, most students agreed, although not very strongly. More students felt that they learned new vocabulary from interacting with others on the wiki $(73.0 \%)$, while $9.5 \%$ disagreed $(\mathrm{M}=3.88)$. This is followed by phrases and sentence structure, to which $68.9 \%$ students agreed, but $9.5 \%$ did not $(\mathrm{M}=3.80)$; and spelling, where $66.2 \%$ felt that they learned correct spelling from their peers, but not for $9.5 \%(\mathrm{M}=3.80)$. However, the most students disagreed that they learned correct grammar when interacting with their group members on the wiki (10.8\%), yet majority of them did (64.9\%) $(\mathrm{M}=3.77)$. AmFi claimed to have improved a lot thanks to his group mates: "Actually, my group mates, Syafik and Adil, both of them are one of the best English speaker in this school. Sometimes, when I did any grammar mistakes, they correct me".

In addition to that, several interviewees mentioned learning different writing styles from observing others on the 
wiki (Baktio, Dino, Law). After reading not only their own group members' writing, but other groups' as well, they aspired to write similarly. Students were also exposed to various styles of writing and organisation. Law said, "Everyone of them has their own way of writing. They did help me to improve my writing skill". However, too many writers with different styles of writing, organising and expressing ideas could make the writing process disorganised. Gemma agreed that "It is hard to work on an essay when you have too much hands to handle it". Some students provided fixed formats to make discussions and writing more organised, others by thorough editing in the writing phase. This implies that other higher-level skills of organisation, writing coherence and editing are required to write effectively collaboratively.

From the study, gifted students reported scrutinising others' language especially in the writing phase and learned by comparing others' writing with their own. A majority of students $(70.3 \%)$ agreed that they paid closer attention to the accuracy of other members' writing on the wiki, but $12.2 \%$ disagreed $(\mathrm{M}=3.77)$. Students also spent more time to read carefully, and compare their writing with those of better learners (Syahira). Furthermore, interaction with peers on the wikis provided an increased exposure to the language and authentic communication and writing, especially for those who seldom used the language (Jud).

Data from the questionnaire showed that a larger majority of students $(79.7 \%)$ felt that they had an improved understanding of the given topic from their interactions on the wiki with peers, with $35.1 \%$ who strongly agreed to the statement, and only $2.7 \%$ who disagreed and none who strongly disagreed. The mean score $(\mathrm{M}=4.12)$ shows the strongest agreement for this statement. Hence, gifted students agreed that they gained better topical knowledge when collaborating on the wiki. Interviewees agreed, benefitting from sharing knowledge about the topic, as well as how to write the essay. Rudolph was amazed at that, saying "I went in blank, came out with my head brimming with ideas on how to write the essay". Moreover, students were exposed to "brilliant" ideas that they never would have thought of on their own (Law). This indicates that interaction on the wikis had a stronger effect on improving topical knowledge in collaborative writing.

From the study, gifted students considered social media like Facebook a better communication tool for announcements and logistic matters than wikis. This implies that the wiki's communication features may be insufficient for collaborative purposes. This becomes a more important issue as gifted students in the study expressed a preference for an offline environment instead of online for group work. Only $20.3 \%$ wished to do the group work online, while almost half (47.3\%) disagreed, with $25.7 \%$ disagreeing completely. A low mean score $(\mathrm{M}=2.53)$ indicates the lowest degree of agreement for completing their group work online instead of offline. This means that most of the gifted students would have preferred to work offline than online.

Rudolph, on the other hand, preferred online group work to offline, and explained that it was simply less of a hassle as he can edit and work on the essay from any location on any computer. Dino agreed to that, yet preferred working offline because "at least if we set an appointment everyone would be...physically there". This is because discussions online are not always synchronous due to different and busy individual schedules, thus affecting the wiki collaborative work. Others just preferred old-school face-to-face communication which was considered clearer and had less room for misunderstandings and confusion. They also believed that certain stages of the writing process, especially brainstorming, were better done face-to-face. Hence, there seems to be a strong inclination and need for face-to-face interaction aside from online among Malaysian gifted students.

\section{Discussion and Conclusion}

In terms of group participation in ESL wiki collaborative writing, there is a range of levels among gifted students. Some had leaders appointed, while others had members who naturally assumed leader roles and delegated tasks. This seems to support characteristics accredited to gifted students, where they may have gifted and talented abilities in the domain of leadership (Aliza \& Hamidah, 2009). Still others did not have clearly assigned leaders or roles. According to the literature, university student groups typically designated a leader and roles to all members to ensure equal contribution to the task (Zailin et al., 2012), and wikis were found to encourage equal participation (Elgort et al., 2008; Zailin et al., 2012). However, whether the contributions were "equal" remains in question. Not all members did their share of the workload, and there was uneven participation, where some members contributed only either at the beginning or the later stages of the project. This was seen as a result of a lack of commitment as well as a tendency to work at the last minute, which other studies have also found (Cole, 2009; Wang, 2012). However, members compensated for each other are slack. Other studies found this as well, whereby more active or better students compensated for the weaker members (Olivo, 2012; Wang, 2012). They were also generally satisfied with respective contributions as they were deemed sufficient. Hence, "equal" contribution is difficult to determine as it cannot be measured merely by the frequency of contributions, as it did not necessarily lead to quality revisions or contributions (Woo et al., 2011). 
In addition, whether wikis promoted genuine collaboration whereby there is mutual engagement throughout the writing process is also questioned. Some still divided the workload and worked separately on the project and even preferred working individually although conceding with the benefits of working collaboratively. This, instead, is the concept of 'cooperation' and not true collaboration which involves all members in mutual engagement in all phases of the task, as defined by Ta-Elhasid and Meishar-Tal (2007). Other studies supported this finding, whereby higher education students divided the work instead of being mutually involved throughout the writing process (Wang, 2012). Thus, the gifted students seem to still possess an individualistic mentality that requires change in order for successful collaborative efforts. However, the Malaysian gifted students are not alone, as other studies reported the same. Higher education students wrote separate paragraphs to identify individual contributions (Wang, 2012), while others worked separately (Zhang et al., 2009) and refused to edit or comment on other members' writing (Lin \& Yang, 2011b).

Similarly, some of the gifted students reportedly preferred working alone. This too is supported by the literature. Studies reported similar findings, where students wanted to work individually instead (Zailin et al., 2012). Others reported that generally, gifted students prefer to work and learn alone (Davis \& Rimm, 2005; Ruf, 2003). From the study, gifted students who had a preference for working alone accounted it to personality reasons. However, French and Shore (2009) argued that it is a situational trait and not a personality one. Despite that, the wiki collaborative writing environment did not really prove that all gifted students preferred working alone. Hence, this study did not really find evidence for a preference for working alone as a trait of gifted students.

Nevertheless, gifted students gained much from their interaction with peers on the wiki CWP. They improved on language aspects, topical knowledge and writing. Studies support this finding where students learned spelling, phrases, vocabulary and sentence structure from observing and interacting with peers (Lin \& Yang, 2011a). The literature also showed that through interactions on the wiki, students became more conscious of writing aspects and language accuracy (Chong et al., 2011; Ma \& Wang, 2012). Other studies also supported that through observing peers' work, students had better topical understanding (Chong et al., 2011; Olivo, 2012). However, an issue arose, which was that collaborative writing on the wiki also involved other skills that students may not possess, including higher-level skills of organisation, writing coherence and editing. Woo et al. (2011) also found that students lacked other skills like note-taking and skimming that may have affected the online collaborative writing process. This could result in difficulties and disorganisation when writing collaboratively.

Moreover, communication features on the wiki were found lacking and the gifted students resorted to other means such as Facebook. Other studies found that students also used email and instant message software as well as face-to-face meetings (Ma \& Wang, 2012) because the wiki discussion forum lacked effective communicative functions and features (Hadjerrouit, 2012). Besides that, it was found that gifted students may have a preference for offline collaborative work rather than online as old-school face-to-face communication was considered clearer and had less room for misunderstandings and confusion. This too was supported by findings in the literature as other students too felt that face-to-face interaction was more effective (Hadjerrouit, 2012; Zailin et al., 2012). Gifted students in the study also felt that certain stages in the writing process were better done face to face, which Ansarimoghaddam and Tan (2013) too found. Therefore, the study has explored ESL wiki collaborative writing among gifted students in terms of group participation and interaction. Several issues and questions have emerged as a result, which are worthwhile to be addressed if wikis are to be successfully incorporated into Malaysian gifted education to motivate and challenge gifted students to achieve their highest potential in English language learning.

\section{Acknowledgments}

The researchers would like to thank the PERMATApintar National Gifted Centre, UKM for allowing students to be part of this research.

\section{References}

Alias, A., \& Ahmad, H. Y. (2009). Ciri kanak-kanak pintar cerdas. In N. M. Ishak, R. A. Majid, \& S. F. M. Yassin (Eds.), PERMATApintar negara: Pengalaman UKM (pp. 33-44). Bangi: Pusat PERMATApintar Negara, UKM.

Anderson, J. (2010). ICT transforming education: A regional guide. Bangkok: UNESCO.

Ansarimoghaddam, S., \& Tan, B. H. (2013). Co-constructing an essay: Collaborative writing in class and on wiki. 3L: The Southeast Asian Journal of English Language Studies, 19(1), 35-50.

Augar, N., Raitman, R., \& Zhou, W. (2004). Teaching and learning online with wikis. Proceedings of ASCILITE 2004. Retrieved from http://ascilite.org.au/conferences/perth04/procs/augar.html 
Barkley, E. F., Cross, K. P., \& Major, C. H. (2005). Collaborative learning techniques: A handbook for college faculty. San Francisco: Jossey-Bass.

Brown, H. D. (2007). Principles of language learning and teaching. New York: Pearson Longman.

Butler-Pascoe, M. (2011). The history of CALL: The intertwining paths of technology and second/foreign language teaching. International Journal of Computer-Assisted Language Learning and Teaching, 1(1), 16-32. http://dx.doi.org/10.4018/ijcallt.2011010102

Carr, T., Morrison, A., Cox, G., \& Deacon, A. (2007). Weathering wikis: Net-based learning meets political science in a South African university. Computers and Composition, 24, 266-284. http://dx.doi.org/10.1016/j. compcom.2007.06.001

Charles, R., \& Ranmi, A. (2007). Wild, Wild Wikis: A way forward. Paper presented at Fifth International Conference on Creating, Connecting and Collaborating through Computing (C5'07), The Computer Society, IEEE. Kyoto: Kyoto University, January. http://dx.doi.org/10.1109/C5.2007.33

Chawner, B., \& Lewis, P. H. (2006). WikiWikiWebs: New ways to communicate in a web environment. Information Technology and Libraries, 25(1), 33-43.

Chong, M. L., Tan, B. H., \& Abdullah, M. H. (2011). Wiki for co-writing a science dictionary. GEMA Online Journal of Language Studies, 11(3), 109-128.

Chu, S. K. W., \& Kennedy, D. M. (2011). Using online collaborative tools for groups to co-construct knowledge. Online Information Review, 35(4), 581-597. http://dx.doi.org/10.1108/14684521111161945

Cole, M. (2009). Using wiki technology to support student engagement: Lessons from the trenches. Computer \& Education, 52, 141-146. http://dx.doi.org/10.1016/j.compedu.2008.07.003

Collis, B., \& Moonen, J. (2008). Web 2.0 tools and processes in higher education: Quality perspectives. Educational Media International, 45(2), 93-106. http://dx.doi.org/10.1080/09523980802107179

Coniam, D., \& Lee, M. W. K. (2008). Incorporating wikis into the teaching of English writing. Hong Kong Teachers' Centre Journal, 7, 52-67.

Davis, G. A., \& Rimm, S. B. (2005). Education of the gifted and talented (5th ed.). Boston, MA: Allyn \& Bacon.

Ebersbach, A., Glaser, M., Heigl, R., \& Warta, A. (2008). Wiki: Web Collaboration (2nd ed.). Berlin, Germany: Springer.

Elgort, I., Smith, A. G., \& Toland, J. (2008). Is wiki an effective platform for group course work? Australasian Journal of Educational Technology, 24(2), 195-210.

French, L. R., \& Shore, B. M. (2009). A reconsideration of the widely held conviction that gifted students prefer to work alone. In B. Hymer, T. D. Balchin, \& D. Matthews (Eds.), The Routledge international companion to gifted education (pp. 176-182). London, England: Routledge.

Godwin-Jones, R. (2008). Mobile-computing trends: Lighter, faster, smarter. Language Learning \& Technology, 12(3), 3-9.

Hadjerrouit, S. (2012). Investigating technical and pedagogical usability issues of collaborative learning with wikis. Informatics in Education-An International Journal, 11(1), 45-64. Retrieved from http://www.mii.lt/ informatics_in_education/pdf/INFE200.pdf

Harper, D. A. (2012). Wiki technology for middle grade students. (Doctoral dissertation, University of Phoenix). Retrieved from http://search.proquest.com.www.ezplib.ukm.my/docview/1267773562?accountid=41453

Hazari, S., North, A., \& Moreland, D. (2009). Investigating pedagogical value of wiki technology. Journal of Information Systems Education, 20(2), 187-198. Retrieved from http://search.proquest.com.ezproxy. apollolibrary.com/docview/200157232/fulltextPDF/12E172C451C1519C525/1?accountid=35812

Kessler, G., Bikowski, D., \& Boggs, J. (2012). Collaborative writing among second language learners in academic web-based projects. Language Learning \& Technology, 16(1), 91-109.

Kimmerle, J., Cress, U., \& Held, C. (2010). The interplay between individual and collective knowledge: Technologies for organizational learning and knowledge building. Knowledge Management Research \& Practice, 8(1), 33-44. http://dx.doi.org/10.1057/kmrp.2009.36

Lightbown, P. M., \& Spada, N. (2006). How languages are learned. Oxford: Oxford University Press.

Lin, W. C., \& Yang, S. C. (2011a). Exploring students' perceptions of integrating wiki technology and peer 
feedback into English writing courses. English Teaching: Practice and Critique, 10(2), 88-103.

Lin, W. C., \& Yang, S. C. (2011b). Using wiki online writing system to develop English writing skills among college students in Taiwan. Curriculum \& Instruction Quarterly, 14(2), 75-102.

Lowry, P. B., Curtis, A., \& Lowry, M. R. (2004). Building a taxonomy and nomenclature of collaborative writing to improve interdisciplinary research and practice. Journal of Business Communication, 41(1), 66-99. http://dx.doi.org/10.1177/0021943603259363

Ma, Y., \& Wang, L. (2012). The study of college English teaching method in collaborate learning environment based on wiki. International Conference on Educational Technology and Management Engineering, 16-17, 474-479. Retrieved from http://www.ier-institute.org/20701918/lnit17/v17/474.pdf

Mak, B., \& Coniam, D. (2008). Using wikis to enhance and develop writing skills among secondary school students in Hong Kong. System, 36(3), 437-455. http://dx.doi.org/10.1016/j.system.2008.02.004

Ministry of Education. (2012). Preliminary report: Malaysia Education Blueprint 2013-2025. Retrieved from www.moe.gov.my/userfiles/file/PPP/Preliminary-Blueprint-Eng.pdf

Munro, J. (2005). Understanding gifted and talented learning. Retrieved from http://online.edfac.unimelb.edu. au/selage/pub/readings/giftedlt/csge\%20gifted\%20learning\%2007B\%20sum2.pdf

O'Reilly, T. (2005). What is Web 2.0: Design patterns and business models for the next generation of software. Retrieved from http://www.oreillynet.com/lpt/a/6228

O’Sullivan, M., \& Samarawickrema, G. (2008). Changing learning and teaching relationships in the educational technology landscape. In Hello! Where are you in the landscape of educational technology? Proceedings Ascilite Melbourne, 711-714.

Olivo, R. F. (2012). Collaborative online writing assignments to foster active learning. The Journal of Undergraduate Neuroscience Education (JUNE), 11(1), A82-A89. Retrieved from http://www.funjournal. org/images/stories/downloads/2012_Volume_11_Issue_1/olivo_11_1_a82_a89.pdf

Omar, H., Embi, M. A., \& Yunus, M. M. (2012). ESL learners' interaction in an online discussion via Facebook. Asian Social Science, 8(11), 67-74. http://dx.doi.org/10.5539/ass.v8n11p67

Pinheiro, P. A. (2012). Collaborative writing by means of digital tools: Resignifying textual production in the school context. Retrieved from http://www.interesjournals.org/IRJASS/pdf/September/Pinheiro.pdf

Resta, P., \& Laferrière, T. (2007). Technology in supporting collaborative learning. Educational Psychology Review, 19(1), 65-72. http://dx.doi.org/10.1007/s10648-007-9042-7

Ruf, D. (2003). Use of the SB5 in the assessment of high abilities. Stanford-Binet Intelligence Scales, Fifth Edition Assessment Service Bulletin No. 3. Itasca, IL: Riverside.

Said, N. E. M., Yunus, M., Doring, L. K., Asmi, A., Aqilah, F., \& Kwan, L. S. L. (2013). Blogging to enhance writing skills: A survey of students' perception and attitude. Asian Social Science, 9(16), 95-101. http://dx.doi.org/10.5539/ass.v9n16p95

Swan, K. (2005). A constructivist model for thinking about learning online. Retrieved from http://www.bradfordvts.co.uk/wponlineresources/0307teachinglearning/constructivism/constructivist $\% 0$ app roach $\% 20$ to $\% 20$ online $\% 20$ learning.PDF

Ta-Elhasid, E., \& Meishar-Tal, H. (2007). Models for activities, collaboration and assessment in wiki in academic courses. Retrieved from http://www.biu.ac.il/bar-e-learn/eden2007/tal_tal.doc

Thompson, L., \& Ku, H. Y. (2006). A case study of online collaborative learning. The Quarterly Review of Distance Education, 7(4), 361-375.

Vygotsky, L. S. (1978). Mind in society. Cambridge, MA: Harvard University Press.

Wang, C. M. (2012). An investigation of using wikis as a collaborative tool for teaching in a non-western tertiary education classroom. Journal of Educational Technology Development and Exchange, 5(1), 63-76. Retrieved from http://www.sicet.org/journals/jetde/jetde12/5-Wang.pdf

Witney, D., \& Smallbone, T. (2011). Wiki work: Can using wikis enhance student collaboration for group assignment tasks? Innovations in Education \& Teaching International, 48(1), 101-110. http://dx.doi.org/10. 1080/14703297.2010.543765

Woo, Y., \& Reeves, T. C. (2007). Meaningful interaction in web-based learning: A social constructivist 
interpretation. Internet and Higher Education 10, 15-25. http://dx.doi.org/10.1016/j.iheduc.2006.10.005

Woo, M., Chu, S., Ho, A., \& Li, X. (2011). Using a wiki to scaffold primary-school students' collaborative writing. Educational Technology \& Society, 14(1), 43-54. Retrieved from http://www.ifets.info/journals /14_1/ets_14_1.pdf

Yin, R. K. (2009). Case study research design and methods. Thousand Oaks: Sage Publications, Inc.

Yunus, M. M., \& Kwan, L. S. L. (2013). Gifted students' use of Web 2.0 technologies for English language learning. International Journal of Computers, 7(1), 22-30.

Yunus, M. M., Kwan, L. S. L., \& Noriah, M. I. (2012). Benefits of using Web 2.0 technologies for English language learning: Gifted students' perception. Proceedings of the 3rd International Conference on Arts and Culture (ICAC '12), Advances in Environment, Computational Chemistry and Bioscience (pp. 385-390).

Yunus, M. M., Sulaiman, A., Kamarulzaman, M. H., \& Ishak, N. M. (2013). Language learning difficulties among Malaysian gifted students. Asian Social Science, 9(15), 130-137. http://dx.doi.org/10.5539/ass. v9n15p130

Zailin, S. Y., Nik Aloesnita, N. A., \& Ainol, H. I. (2012). Investigating students' perception of using wikis in academic writing. The Southeast Asian Journal of English Language Studies, 18(3), 91-102.

Zhang, K., Peng, S. W., \& Hung, J. L. (2009). Online collaborative learning in a project-based learning environment in Taiwan: A case study on undergraduate students' perspectives. Educational Media International, 46(2), 123-135. http://dx.doi.org/10.1080/09523980902933425

Zou, B., Xiang, C. H., \& Jeaco, S. (2012). An investigation of the use of wikis in English language learning. Chinese Journal of Applied Linguistics (Quarterly), 35(1), 99-116. Retrieved from http://www.celea.org.cn /teic/99/8.pdf

\section{Copyrights}

Copyright for this article is retained by the author(s), with first publication rights granted to the journal.

This is an open-access article distributed under the terms and conditions of the Creative Commons Attribution license (http://creativecommons.org/licenses/by/3.0/). 